\title{
Trends of the Occupation by Municipality in Time of Crisis in the Border State of Baja California
}

\author{
Antonio Escamilla Díaz', Alejandro Mungaray Lagarda², Gerardo Huber Bernal2* \\ ${ }^{1}$ Faculty of Economics, Autonomous University of Coahuila, Coahuila, Mexico \\ ${ }^{2}$ Faculty of Economics and International Relations, Autonomous University of Baja California, Baja California, Mexico \\ Email:edantonio_10@hotmail.com,mungaray@uabc.edu.mx, *gerardo.huber@uabc.edu.mx
}

How to cite this paper: Díaz, A.E., Lagarda, A.M. and Bernal, G.H. (2017) Trends of the Occupation by Municipality in Time of Crisis in the Border State of Baja California. Open Journal of Social Sciences, 5, 59-75. https://doi.org/10.4236/jss.2017.512005

Received: November 9, 2017

Accepted: December 10, 2017

Published: December 13, 2017

Copyright @ 2017 by authors and Scientific Research Publishing Inc. This work is licensed under the Creative Commons Attribution International License (CC BY 4.0).

http://creativecommons.org/licenses/by/4.0/

\begin{abstract}
In order to obtain series of occupied population of Baja California and to assess the impacts of the national migration in the occupation levels those corresponding to five municipalities were estimated by using weights of the occupied population against the total taking as reference the report of employed population ENOE/INEGI for Baja California and Tijuana in the 2005-2015 period. The results indicate a common behavior of the occupation in the metropolitan zone Tijuana-Tecate-Playas de Rosarito, while Mexicali and Ensenada show a differentiated behavior. Also, the changes in the economically active population, the occupied population in the regions of the country as well their impact in the occupation level in the State and each one of their municipalities are analyzed, in a scene where increases in the unemployment rate are imported from other States ejectors of labor force.
\end{abstract}

\section{Keywords}

Occupation, Migration, Economically Active Population

\section{Introduction}

The growing need of economic information disaggregated at the municipal level that allows to improve decision-making in a globalized environment and in continuous change requires practical solutions. In the present work, series of economically active population (PEA) are estimated, employed population (PO) and rate of unemployment (TD) by municipality in Baja California (BC).

The review of information of National Survey of Occupation and Employment (ENOE) and the Census and Counts of Population and Housing-elaborated by 
National Institute of Statistics and Geography (INEGI) - coincides with the traditional vision of the migratory flows from the South to the North. The available data show that increases of the PEA in Baja California remain practically constant in the federal entities with greater migratory flow towards the State, showing how increases in the unemployment rate are imported from the entities where the population treks in search of better employment opportunities.

While the Mexican Social Security Institute (IMSS) provides disaggregated data of insured persons per delegation, it is necessary to consider that these reports contain partial information that does not reflect the behavior of the labor market, because apart from the fact that it only presents data on less than $50 \%$ of the total employed population, it should be considered that, in accordance with the article 13 of the Law of the IMSS, they are exempt from insurance to the mandatory regime the following cases: 1) Workers in family industries and independents, such as professionals, little merchants, craftsmen and other self-employed workers; 2) Domestic workers; 3) the ejidatarios, comuneros, settlers and small landowners; 4) The patterns physical persons with workers secured to its service and 5) Workers at the service of the public administrations of the Federation, States and municipalities that are excluded or misunderstood in other laws or decrees as subjects of social security [1].

Through weightings of occupation with respect to the participation of each municipality in the total population and the estimation of regression equations, results are obtained and they indicate a common and growing behavior of the PEA, the PO and the TD in five municipalities of the State, being notoriously more similar in the metropolitan area of Tijuana (formed by the municipalities of Tijuana, Tecate and Rosarito), while Mexicali and Ensenada, each one on their own way, show a behavior relatively differentiated.

The document is organized in the following way: first the trends in the evolution of the PEA are reviewed, occupation, and TD in the regions of the country; then, the implications of these trends are checked for Baja California in order to consider aspects related to the method used to estimate the occupancy by municipality; in Section 4, the results of the estimates made are analyzed and it's concluded with some final thoughts.

\section{Regional Trends of Occupation and PEA}

It is generally accepted that changes in the population would occur from the peripheral entities to the geographical and industrial center of the country; however, as a result of the process of trade liberalization and its deepening with the signing of the North American Free Trade Agreement (NAFTA), flows of people have intensified towards the States of the northern border of the country, following the intense industrial deconcentration process ([2]-[8] and [9]; among others).

According to the information from the 2005 Count, the 2010 census and the count 2015 from INEGI, the net balance (whereas the arrival and departure of 
population 5 years and more that in 2000 had their place of residence in another State) added 436,386 people who arrived to the northern region; 201,552 , to the Centre-North; 249,499 to the Center; 173,293 to the Pacific; 29,451, to the Gulf; $-528,448$, to the South and $-557,780$, to the capital. This demonstrates a clear migratory movement towards the regions of the Centre-North and North of the country.

At the level of entities, the net balance of inputs and outputs is 184,584 added people to BC; 44,358, to Sonora; $-19,370$, to Chihuahua; 2634 to Coahuila de Zaragoza; 524,193, to Nuevo León and 30 - 656, to Tamaulipas. Moreover, in the same period, the net population that came and went out of the State of Mexico and the city of Mexico (DF) was of $-1,024,464$ and 466,584 people, in that order. Here it should be considered that output of individuals of the DF coincides with the arrival of 249,499 people in its peripheral region which is, mainly, the central region.

In a pioneer way, Marshall (1927) argued that the companies are likely to resort to places where it is more likely to find workers with the skills that they require, while people will seek employment in places where companies that need skills like theirs are located [10]. In a perspective of proper markets perspective, the analysis of migration flows shows the northern region as the main pole of attraction for migrants in the posterior trade liberalization era. This has led to the observation of an increase in the PEA, the PO and the major TD bigger than in other regions of the country, noting a strong pressure of the PEA increase in the TD [11].

The evolution of these three indicators for the North and North-Central regions indicates that between the second quarters of 2000 and 2015 the uneven growth of the economically active population has led to an extension of the distance between the levels of PEA of each region. While in the North the PEA increased 39\%, in the North-Central it increased 36\%. The higher pressure of the PEA on these labor markets led to the fact that, while the PO rose $36 \%$ in the North and $33 \%$ in the Centre-North, TD increased in great magnitude in the North going from $2.6 \%$ to $4.8 \%$, while in the Center-North went from $2.4 \%$ to 4.1\% (see Tables 1-3).

The Pacific region increased its PEA 36\% and his PO 33\%; both numbers are smaller than in the North and it, however had a greater increase in his TD, which went from 2.6 to 5 per cent. The Gulf, rose its levels $29 \%$ and $27 \%$, respectively, with which presented a smaller increase in its TD from 2.1 to 3.7 per cent. For its part, the South increased $19 \%$ and $18 \%$ and his TD rose from $1.6 \%$ to 2.7\% (see Tables 1-3).

The Centre and Capital regions show a behavior that could be determined by the decisions of change of address of people to places less congested, but close to their places of work in the suburbs of Mexico City: the first region noted an increase in the economically active population of $40 \%$ and $39 \%$ of the PO, while the Capital registered an increase of $29 \%$ and $26 \%$, respectively with changes in the $2.2 \%$ to $3.6 \%$ and $3.5 \%$ to $5.5 \% \mathrm{TD}$, each one. 
Table 1. PEA by regions.

\begin{tabular}{cccccccc}
\hline Period & North & Center-North & Pacific & Center & Capital & Gulf & South \\
\hline $2000 / \mathrm{II}$ & $7,027,674$ & $4,695,167$ & $4,532,043$ & $3,757,490$ & $9,114,254$ & $4,881,046$ & $5,863,638$ \\
2001/II & $7,027,178$ & $4,686,072$ & $4,756,554$ & $3,877,167$ & $9,063,225$ & $4,696,880$ & $5,779,833$ \\
2002/II & $7,194,658$ & $4,962,580$ & $4,801,368$ & $4,039,654$ & $9,195,252$ & $4,826,589$ & $5,916,377$ \\
2003/II & $7,260,900$ & $4,997,066$ & $4,862,301$ & $4,113,640$ & $9,261,468$ & $4,931,563$ & $5,846,054$ \\
2004/II & $7,623,406$ & $5,131,667$ & $5,022,956$ & $4,380,103$ & $9,870,662$ & $5,191,136$ & $5,763,004$ \\
$2005 / \mathrm{II}$ & $7,794,761$ & $5,118,643$ & $5,025,203$ & $4,315,807$ & $9,842,143$ & $5,135,291$ & $5,948,585$ \\
$2006 / \mathrm{II}$ & $8,166,810$ & $5,264,827$ & $5,137,447$ & $4,510,115$ & $10,145,827$ & $5,343,920$ & $6,042,726$ \\
$2007 / \mathrm{II}$ & $8,357,187$ & $5,395,328$ & $5,243,538$ & $4,548,773$ & $10,292,846$ & $5,632,211$ & $6,099,512$ \\
$2008 / \mathrm{II}$ & $8,732,499$ & $5,535,441$ & $5,490,286$ & $4,619,404$ & $10,549,562$ & $5,762,727$ & $6,216,002$ \\
$2009 / \mathrm{II}$ & $8,720,221$ & $5,566,039$ & $5,466,579$ & $4,633,474$ & $10,767,264$ & $5,833,772$ & $6,465,814$ \\
$2010 / \mathrm{II}$ & $8,863,944$ & $5,820,948$ & $5,731,355$ & $4,833,081$ & $11,083,585$ & $6,083,458$ & $6,716,761$ \\
$2011 / \mathrm{II}$ & $8,933,941$ & $5,904,823$ & $5,788,377$ & $4,847,893$ & $11,072,613$ & $6,049,520$ & $6,884,945$ \\
$2012 / \mathrm{II}$ & $9,455,698$ & $6,171,500$ & $5,988,359$ & $5,071,919$ & $11,463,286$ & $6,332,268$ & $6,994,148$ \\
$2013 / \mathrm{II}$ & $9,652,424$ & $6,212,511$ & $6,099,732$ & $5,144,064$ & $11,598,364$ & $6,309,234$ & $6,879,536$ \\
$2014 / \mathrm{II}$ & $9,651,752$ & $6,217,445$ & $5,994,391$ & $5,200,733$ & $11,670,016$ & $6,198,628$ & $6,903,787$ \\
$2015 / \mathrm{II}$ & $9,781,489$ & $6,361,458$ & $6,171,346$ & $5,276,076$ & $11,756,257$ & $6,307,667$ & $6,969,428$ \\
\hline
\end{tabular}

Source: INEGI. ENOE.

Table 2. Population occupied by regions.

\begin{tabular}{cccccccc}
\hline Period & North & Center-North & Pacific & Center & Capital & Gulf & South \\
\hline $2000 / \mathrm{II}$ & $6,847,318$ & $4,583,604$ & $4,414,768$ & $3,674,754$ & $8,799,533$ & $4,777,270$ & $5,767,370$ \\
$2001 / \mathrm{II}$ & $6,831,959$ & $4,578,148$ & $4,627,168$ & $3,797,768$ & $8,749,444$ & $4,591,324$ & $5,707,830$ \\
$2002 / \mathrm{II}$ & $6,880,813$ & $4,845,606$ & $4,645,188$ & $3,947,978$ & $8,884,010$ & $4,736,502$ & $5,840,896$ \\
$2003 / \mathrm{II}$ & $6,970,620$ & $4,828,865$ & $4,722,299$ & $4,036,262$ & $8,903,039$ & $4,834,320$ & $5,770,428$ \\
$2004 / \mathrm{II}$ & $7,314,780$ & $4,937,002$ & $4,832,905$ & $4,269,915$ & $9,333,337$ & $5,056,711$ & $5,682,485$ \\
$2005 / \mathrm{II}$ & $7,526,860$ & $4,934,023$ & $4,878,584$ & $4,182,600$ & $9,311,268$ & $5,009,191$ & $5,834,342$ \\
$2006 / \mathrm{II}$ & $7,880,630$ & $5,106,089$ & $5,001,217$ & $4,377,913$ & $9,681,318$ & $5,228,375$ & $5,936,892$ \\
$2007 / \mathrm{II}$ & $8,063,524$ & $5,235,384$ & $5,093,761$ & $4,407,108$ & $9,756,656$ & $5,497,499$ & $5,996,996$ \\
$2008 / \mathrm{II}$ & $8,382,134$ & $5,332,091$ & $5,336,059$ & $4,478,911$ & $10,046,502$ & $5,623,098$ & $6,094,821$ \\
$2009 / \mathrm{II}$ & $8,144,473$ & $5,272,958$ & $5,236,822$ & $4,425,005$ & $10,008,377$ & $5,633,584$ & $6,305,885$ \\
$2010 / \mathrm{II}$ & $8,278,670$ & $5,499,695$ & $5,462,239$ & $4,618,671$ & $10,340,722$ & $5,858,989$ & $6,538,638$ \\
$2011 / \mathrm{II}$ & $8,361,852$ & $5,555,415$ & $5,472,502$ & $4,606,648$ & $10,373,268$ & $5,811,471$ & $6,710,430$ \\
$2012 / \mathrm{II}$ & $8,887,084$ & $5,852,122$ & $5,716,875$ & $4,854,625$ & $10,761,847$ & $6,102,909$ & $6,827,918$ \\
$2013 / \mathrm{II}$ & $9,096,494$ & $5,890,531$ & $5,807,980$ & $4,921,167$ & $10,869,479$ & $6,048,799$ & $6,661,779$ \\
$2014 / \mathrm{II}$ & $9,167,470$ & $5,916,303$ & $5,682,026$ & $4,979,369$ & $10,891,307$ & $5,951,532$ & $6,713,550$ \\
$2015 / \mathrm{II}$ & $9,316,145$ & $6,101,893$ & $5,862,797$ & $5,088,167$ & $11,108,395$ & $6,074,358$ & $6,784,333$ \\
\hline
\end{tabular}

Source: INEGI. ENOE. 
Table 3. TD by regions.

\begin{tabular}{cccccccc}
\hline Period & North & Center North & Pacific & Center & Capital & Gulf & South \\
\hline $2000 / \mathrm{II}$ & 2.6 & 2.4 & 2.6 & 2.2 & 3.5 & 2.1 & 1.6 \\
$2001 / \mathrm{II}$ & 2.8 & 2.3 & 2.7 & 2.0 & 3.5 & 2.2 & 1.2 \\
$2002 / \mathrm{II}$ & 4.4 & 2.4 & 3.3 & 2.3 & 3.4 & 1.9 & 1.3 \\
$2003 / \mathrm{II}$ & 4.0 & 3.4 & 2.9 & 1.9 & 3.9 & 2.0 & 1.3 \\
$2004 / \mathrm{II}$ & 4.0 & 3.8 & 3.8 & 2.5 & 5.4 & 2.6 & 1.4 \\
$2005 / \mathrm{II}$ & 3.4 & 3.6 & 2.9 & 3.1 & 5.4 & 2.5 & 1.9 \\
$2006 / \mathrm{II}$ & 3.5 & 3.0 & 2.7 & 2.9 & 4.6 & 2.2 & 1.8 \\
$2007 / \mathrm{II}$ & 3.5 & 3.0 & 2.9 & 3.1 & 5.2 & 2.4 & 1.7 \\
$2008 / \mathrm{II}$ & 4.0 & 3.7 & 2.8 & 3.0 & 4.8 & 2.4 & 1.9 \\
$2009 / \mathrm{II}$ & 6.6 & 5.3 & 4.2 & 4.5 & 7.0 & 3.4 & 2.5 \\
$2010 / \mathrm{II}$ & 6.6 & 5.5 & 4.7 & 4.4 & 6.7 & 3.7 & 2.7 \\
$2011 / \mathrm{II}$ & 6.4 & 5.9 & 5.5 & 5.0 & 6.3 & 3.9 & 2.5 \\
$2012 / \mathrm{II}$ & 6.0 & 5.2 & 4.5 & 4.3 & 6.1 & 3.6 & 2.4 \\
$2013 / \mathrm{II}$ & 5.8 & 5.2 & 4.8 & 4.3 & 6.3 & 4.1 & 3.2 \\
$2014 / \mathrm{II}$ & 5.0 & 4.8 & 5.2 & 4.3 & 6.7 & 4.0 & 2.8 \\
$2015 / \mathrm{II}$ & 4.8 & 4.1 & 5.0 & 3.6 & 5.5 & 3.7 & 2.7 \\
\hline
\end{tabular}

Source: INEGI. ENOE.

The migration phenomenon and changes in the PEA also contains medium-term effects, as in accounting persons 5 years and over that change of address, there is an observed movement in which, usually, adults arrive accompanied by relatives to with the pass of time, are integrated into the workforce in their new place of residence.

In short, information about the recent performance of the PEA by regions in Mexico confirms the greater dynamic (even in the tough times that the world economy traverses) in the northern region in relation to the rest of the areas of the country.

\section{Baja California in Migration Context and Changes in the PEA in the Country}

The PEA, PO, and TD of Baja California reported by the ENOE are strongly impacted by the migratory movements of all regions of the country, although according to the count 2005 by INEGI, mostly by flows of people coming from the regions Pacific South and North, with a net balance of 62,030, 38,920 and 23,022 individuals, respectively. However, the State also has a positive balance with the other regions: with the Capital of 88,214 , with the Gulf of 98,213 , with the Centre-North of 10,008 and with the Centre of 7325 people. At the level of 
entities, the migratory movements of people over 5 years coming to the State of Sinaloa $(37,861)$, Sonora $(18,358)$, Chiapas $(15,674)$ and Jalisco $(11,750)$ stand out.

The flow of people from Sinaloa contributes to the PEA of BC to increase $81 \%$ between 1996 and the second quarter of 2010, while the Sinaloa PEA maintains a more moderate growth of $42 \%$, as you can see in Figure 1. Furthermore, while the Sinaloa PEA remains almost constant from the first quarter of 2004, the PEA of Baja California shows growth sustained over time.

Due to the geographical neighborhood, Sonora excels as the second entity with more immigration presence in the State. Figure 2 shows that the variation in its PEA (with an increase of 56\% between 1996 and the second quarter of 2015 ) is less than the increase in Baja California. The greater magnitude of the gap during the peak of the crisis is noticeable. By 2015 the distance in the growth of the PEA between the two entities is 25 percentage points.

Chiapas is the third State in importance in migratory flows to the State and, as in previous cases, there is a clear difference in the evolution of the PEA and PO between them, because in the first one it has increased $31 \%$ in the period of 15 years, situation that has kept its TD almost constant at around $2.7 \%$. To make this possible, the 15,674 people who left Chiapas and added themselves to BC play a key role (see Figure 3 ).

Jalisco is located in fourth place among the States suppliers of migrants to the entity and a distance is remained in the evolution of the PEA and PO between both, as in the previous cases. Even though, the growth of the PEA (43\%) from 1996 to the second quarter of 2010 allows the difference in growth to be of 42 percentage points among PEA of the two States (see Figure 4).

The intensity of the migration phenomenon towards $\mathrm{BC}$ propitiates that, between 2000 and 2005, only these four entities contribute with their migration equivalent to $5.9 \%$ of the Economically Active Population of the State in the second quarter of 2010 (Sinaloa 2.7\%, Sonora 1.3\%, Jalisco 1.1\% and Chiapas $0.8 \%$ ). In the context of the northern border, the strongest migratory movement for Baja California is the one that is kept with Sonora.

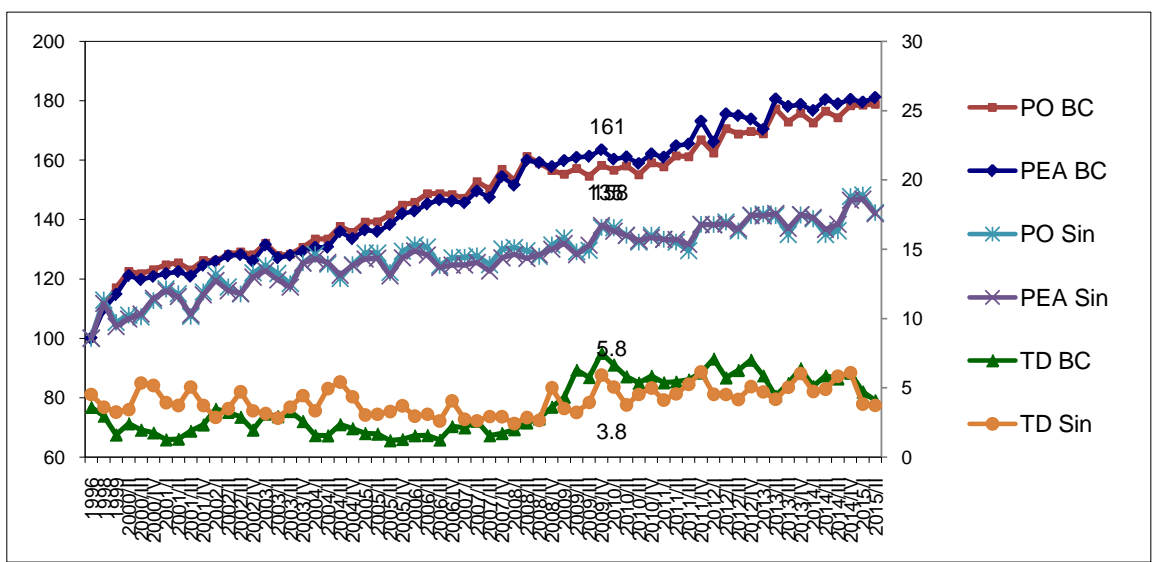

Figure 1. Rates of increase in PO, PEA and TD Baja California and Sinaloa 1996-2015. Source: Own elaboration with INEGI, ENOE data. 


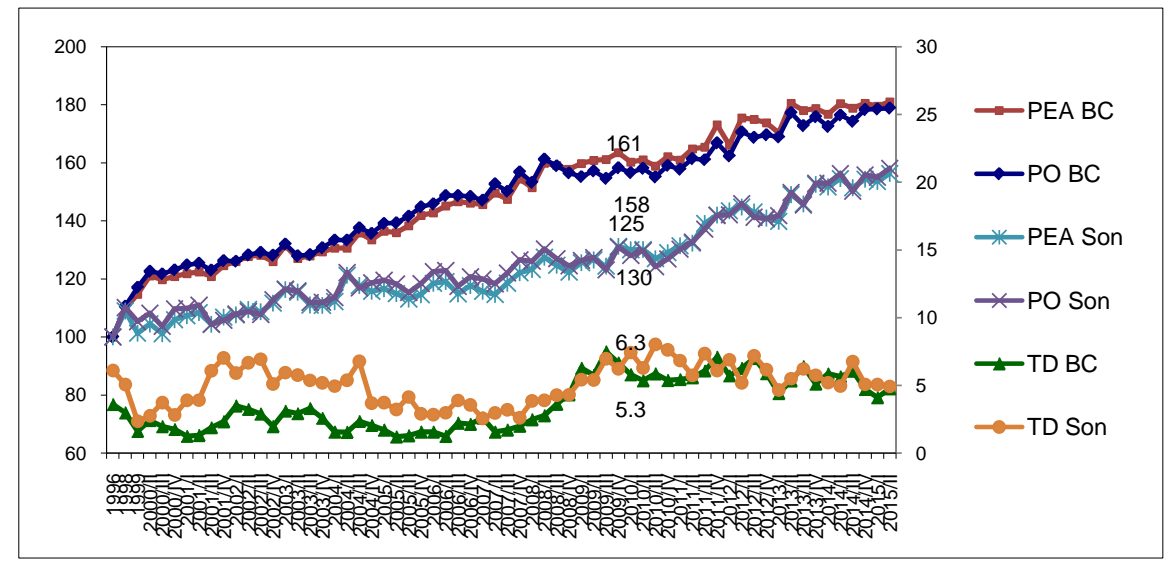

Figure 2. Increase rates in PO, PEA and TD Baja California and Sonora, 1996-2015. Source: Own elaboration with INEGI, ENOE data.

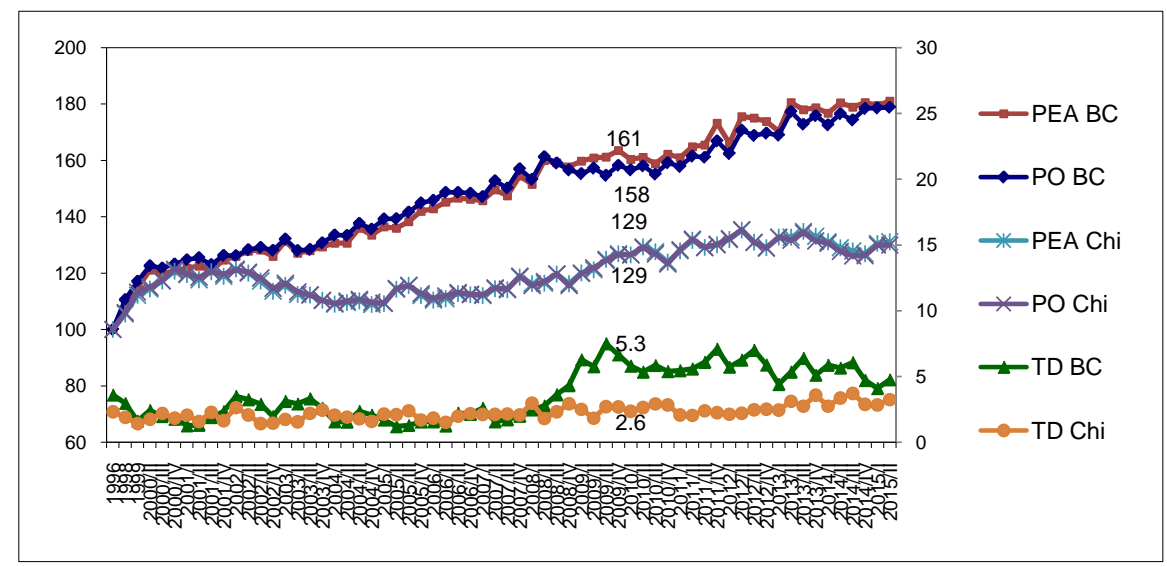

Figure 3. Increase Rates in PO, PEA and TD Baja California and Chiapas 1996-2015. Source: Own elaboration with INEGI, ENOE data.

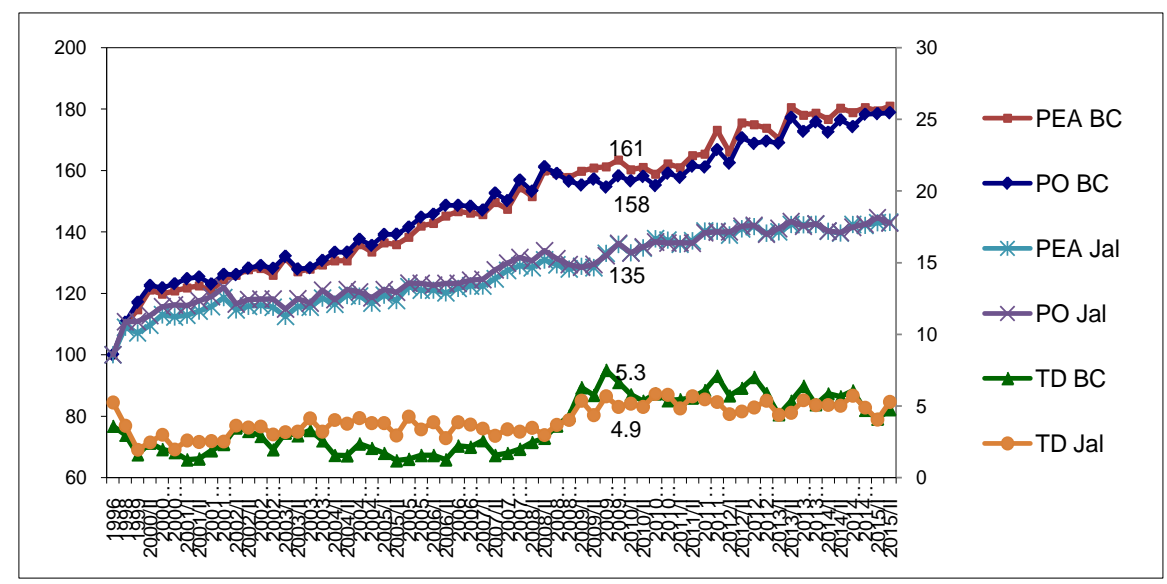

Figure 4. Increase rates in PO, PEA and TD in Baja California and Jalisco, 1996-2015. Source: Own elaboration with INEGI, ENOE data.

In accordance with the Count 2005, the balance net of inputs and outputs of people to $\mathrm{BC}$ was of 111,040 people, superior by 49,460 to the migration to the 
State closer in positive balance immigration that is Tamaulipas, by 63,689 to Nuevo León, by 86,949 to Chihuahua, by 103,441 to Sonora and 108,828 to Coahuila de Zaragoza. This helps in a determinant way the evolution of the PEA on the border.

As seen in Table 4, between 1996 and the second quarter of 2010 the Baja California PEA rose from 870,443 to $1,575,652$; Sonora's, of 889,413 to $1,390,367$; Chihuahua's, $1,113,051$ to $1,598,241$; Coahuila's, of 917,305 to $1,319,515$; Nuevo Leon's, of 1,554,625 to 2,327,113 and Tamaulipas', of 1,072,492 to $1,570,601$. No matter that they are different sizes of labor market, these numbers represent increases in the period of $81 \%$ for Baja California, for Sonora $56.3 \%$, for Nuevo León 50\%, Tamaulipas 46\%, for Coahuila de Zaragoza and for Chihuahua 44\%.

The fact that Baja California and Nuevo Leon are two of the three States with increased flow of migrants in the region (according to the 2005 Count), and all three of the greatest increase in the economically active population from 1996 to 2015, confirms the existence of a direct relationship between migration and growth of the PEA, with consequential impacts on the occupation level and TD in the receivers.

Table 4. PEA by entity of northern border.

\begin{tabular}{|c|c|c|c|c|c|c|}
\hline Period & Baja California & Sonora & Chihuahua & Coahuila & Nuevo León & Tamaulipas \\
\hline 1996 & 870,443 & 889,413 & $1,113,051$ & 917,305 & $1,554,625$ & $1,072,492$ \\
\hline 1998 & 955,737 & 968,921 & $1,152,021$ & 964,229 & $1,634,494$ & $1,130,473$ \\
\hline 1999 & 998,285 & 900,671 & $1,238,582$ & 929,278 & $1,606,546$ & $1,111,913$ \\
\hline 2000/II & $1,053,934$ & 929,511 & $1,229,838$ & 956,434 & $1,678,329$ & $1,178,076$ \\
\hline 2001/II & $1,066,003$ & 964,365 & $1,206,678$ & 938,237 & $1,673,625$ & $1,177,473$ \\
\hline 2002/II & $1,111,988$ & 973,498 & $1,227,875$ & 967,776 & $1,702,847$ & $1,210,131$ \\
\hline 2003/II & $1,105,912$ & $1,027,139$ & $1,220,705$ & 968,210 & $1,747,161$ & $1,191,905$ \\
\hline 2004/II & $1,136,880$ & $1,078,427$ & $1,246,470$ & $1,030,711$ & $1,848,063$ & $1,282,991$ \\
\hline 2005/II & $1,183,093$ & $1,022,125$ & $1,314,058$ & $1,035,991$ & $1,919,994$ & $1,319,500$ \\
\hline 2006/II & $1,263,649$ & $1,059,200$ & $1,410,645$ & $1,084,911$ & $2,001,960$ & $1,346,445$ \\
\hline 2007/II & $1,302,074$ & $1,019,643$ & $1,445,746$ & $1,122,479$ & $2,058,098$ & $1,409,147$ \\
\hline 2008/II & $1,391,828$ & $1,133,964$ & $1,483,542$ & $1,164,475$ & $2,108,675$ & $1,450,015$ \\
\hline 2009/II & $1,400,121$ & $1,125,327$ & $1,445,058$ & $1,157,255$ & $2,155,024$ & $1,437,436$ \\
\hline 2010/II & $1,401,569$ & $1,157,423$ & $1,439,191$ & $1,187,554$ & $2,226,394$ & $1,451,813$ \\
\hline 2011/II & $1,434,978$ & $1,177,126$ & $1,373,310$ & $1,238,971$ & $2,199,831$ & $1,509,725$ \\
\hline 2012/II & $1,527,672$ & $1,287,307$ & $1,500,705$ & $1,279,688$ & $2,311,406$ & $1,548,920$ \\
\hline 2013/II & $1,571,599$ & $1,325,809$ & $1,565,371$ & $1,323,854$ & $2,315,207$ & $1,550,584$ \\
\hline 2014/II & $1,570,158$ & $1,374,834$ & $1,541,646$ & $1,312,612$ & $2,296,696$ & $1,555,806$ \\
\hline 2015/II & $1,575,652$ & $1,390,367$ & $1,598,241$ & $1,319,515$ & $2,327,113$ & $1,570,601$ \\
\hline
\end{tabular}

Source: INEGI. ENOE. 
In summary, the above information confirms that, derived from the increased participation of the northern region on migratory flows and the dynamics of the PEA and that within the three entities of the North with greater flow of people is $\mathrm{BC}$ and NL, the evolution of their PEA and PO shows a shift of greater magnitude than the rest of the region as a whole, which strengthens them as the main receiving States of labor force in search of better life opportunities.

\section{Methodology}

Using weights of municipal participation in the total population series with disaggregation of PO, PEA, and TD are generated in the municipalities and regressions are run to assess the possible presence of autocorrelation which could generate the procedure.

\subsection{Population Occupied by Municipality}

The employed population and the total of Baja California and Tijuana was considered; also, the annual population of the other municipalities was taken into account, the participation of the municipalities in the total population of Baja California, and a weighting was made to adjust it to the total population of Baja California, leaving the population of Tijuana.

The PO of each municipality was obtained by applying their participation in the total population to the total employed population of Baja California:

$$
P_{i}=(P T M i / P T E) * P O E
$$

where:

$P O M_{i}$ population employed in the municipality.

$P T M_{i}$ : total population in the municipality.

$P T E$ : total population in the State.

POE: population occupied in the State.

\subsection{Autocorrelation for Occupation by Municipality}

To assess the presence of autocorrelation which could be generated by the use of municipal participation in the total population as weighting, there is a model which is run of total population against population occupied by municipality.

The result was that in the State in general, Tijuana and Tecate total population reacts belatedly to the movements of the employed population. Whereas, in the case of Rosarito and Ensenada there is no autocorrelation in the residuals. Moreover, in the case of Mexicali autocorrelation is seen.

\subsection{PEA by Municipality}

An analogous procedure to the effected is made for the series of PO by municipality to estimate the PEA with the same level of disaggregation and the following equation is applied:

$$
P{ }^{2} M_{i}=(P T M i / P T E) * P E A E
$$

where: 
PEAM: economically active population in the municipality.

$P E A$ : economically active population in the State.

While the lack of disaggregated information to a municipal level provokes that, so far, (and following common practices) it is necessary to make estimates of this kind, the advance in the same generation will allow estimates with more elaborate methods.

\section{Results}

Estimates of the three indices for Mexicali, Ensenada, Tecate, Rosarito and Tecate-Tijuana-Rosarito metropolitan area show that the municipalities of the entity share common trends, in different magnitudes, though. The phenomenon of migration from the information of the occupation of the ENOE can be analyzed in the particular case of Tijuana. The results obtained show that migration is determinant in the composition and dynamics of the labor market in the five municipalities of the State and highlight the need for countervailing federal policies to confront a complex and growing phenomenon over time.

\subsection{Tijuana}

This city stands the migratory movement of individuals from Sinaloa (21,238 people), Chiapas (12,405), Veracruz de Ignacio de la Llave (7948), Jalisco (7353) and Sonora (6941) as the States with major flows of individuals towards the city. Nonetheless, also Michoacan de Ocampo (5628), Nayarit (5390), Mexico (5013), DF (4643) and Guerrero (4157) have significant presence.

In Figure 5, you can see that the Tijuana PEA increases in greater proportion than the major States with immigration presence immigration presence. Between the second quarter of 2005 and the second in 2015, the PEA in Tijuana increased 25\%; in Sinaloa, only 12\%; in Chiapas, 20\%; Veracruz's Ignacio de la Llave, 14\%; in Jalisco, 920\%. Only Sonora's showed an increase in wholesale, 34 percent. This strengthens the evidence around the phenomenon of increase in the economically active population as a result of the migratory flow and their consequential impact on the unemployment rate.

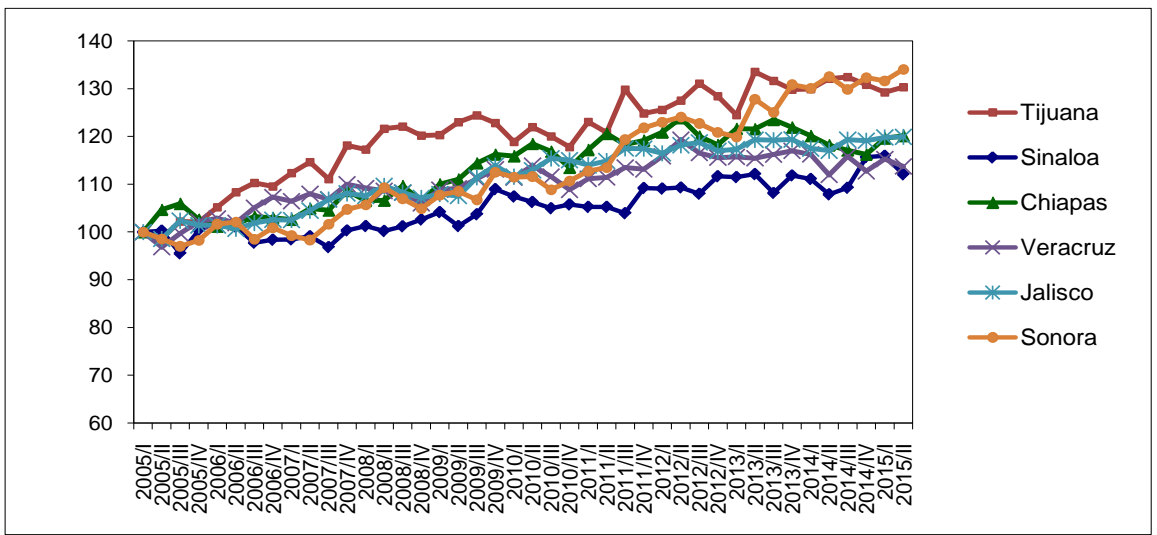

Figure 5. Index of PEA in Tijuana, Sinaloa, Chiapas, Veracruz de ignacio de la llave, Jalisco and Sonora. Source: Own elaboration with INEGI, ENOE data. 
The PO of Tijuana, in spite of having pressures arising from the global crisis, it maintains a growing trend in the medium term, and between the second quarter of 2005 and the second in 2015 it noted a 27 percent increase, however, this fails to compensate the increase in the economically active population of $30 \%$ which, consequently, generates an increase in the TD that passes from $2.4 \%$ to 4.5\%; also after having its lowest point in the fourth quarter of 2010 with 579,013 busy people, it's been achieved to increase the occupation to a level of 649,639 workers (see Figure 6).

\subsection{Mexicali}

In the capital of the State the same entities with greater migratory flow than in Tijuana are maintained, with the particularity that, due to the proximity of the Sonoran town of San Luis Río Colorado, mentioned entity located in second place and Chiapas displaced to the fifth. Figure 7 shows that growth in the economically active population of Mexicali remains above entities that have stronger immigration presence in the municipality. Similarly, a greater distance in the increase of the PEA is observed as the migratory flow is greater, the Mexicali's one increases $30 \%$ and Sinaloa's (main provider entity of migrants to the municipality) increases $12 \%$; the difference from other entities is ten points with Jalisco and Chiapas, sixteen with Veracruz de Ignacio de la Llave and only Sonora has variation of PEA increased by 4 percentage points.

Mexicali PO kept their growing tendency between the second quarter of 2005 and the second in 2015 and the 495661 people have a level of employment greater than the one observed before the crisis $(438,723)$. However, to have a total increase in the period of $26 \%$ in the employed population, the TD showed an increase from 1 to $4.4 \%$, less than the peak of $7.1 \%$ amount seen in the fourth quarter of 2011 (see Figure 8).

\subsection{Ensenada}

The municipality has the most atypical situation between the ones of the State. Sinaloa (with 4930 people) continues to be the main source of migrants;

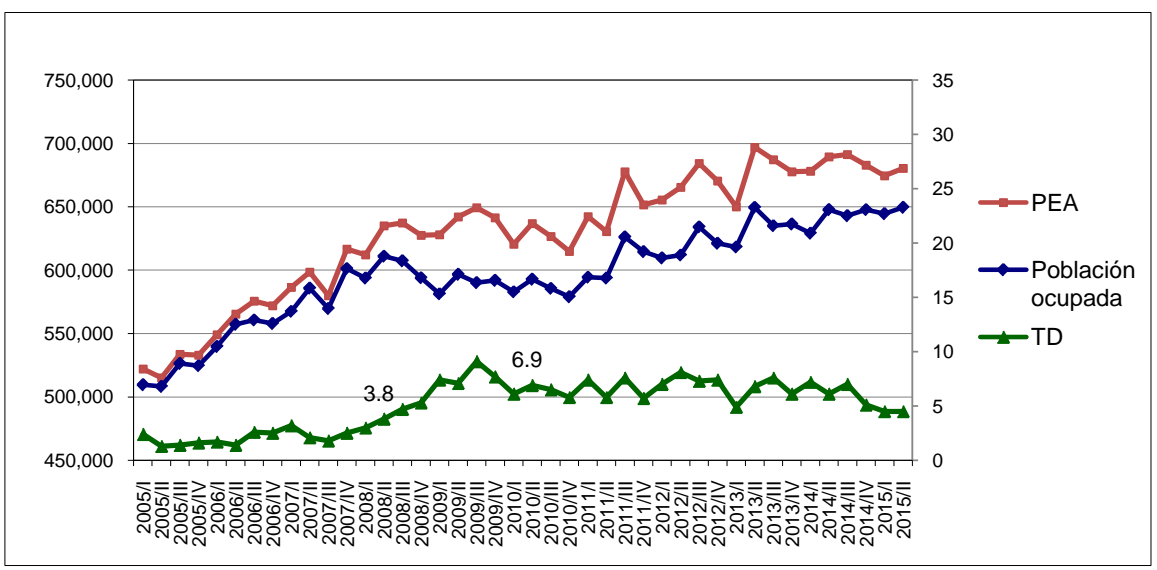

Figure 6. PO, PEA and TD in Tijuana. Source: Own elaboration INEGI, ENOE data. 


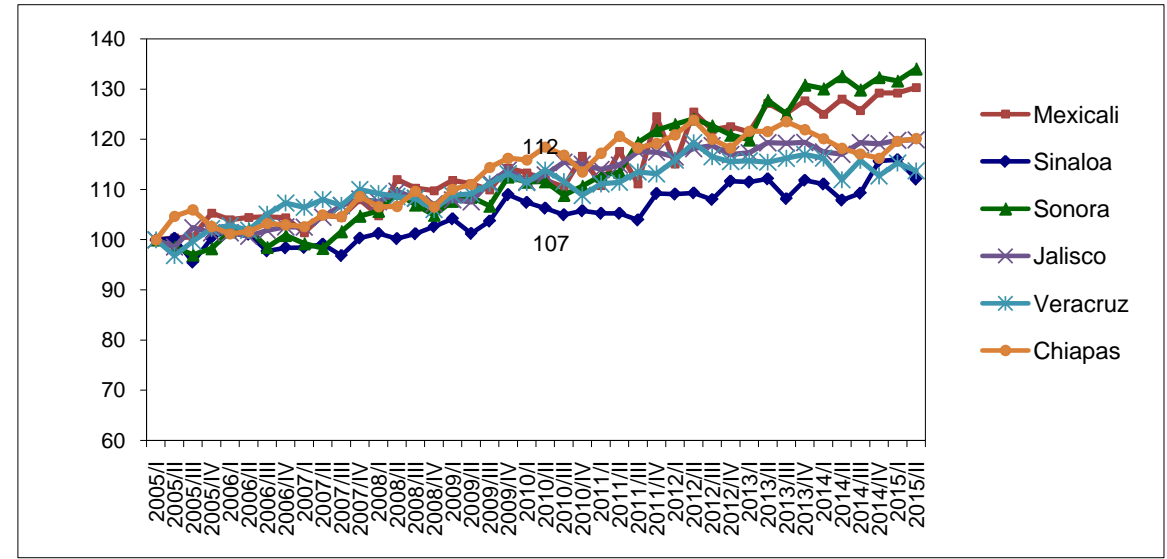

Figure 7. Index of PEA in Mexicali, Sinaloa, Sonora, Jalisco, Veracruz de Ignacio de la Llave, and Chiapas. Source: Own elaboration with INEGI, ENOE data.

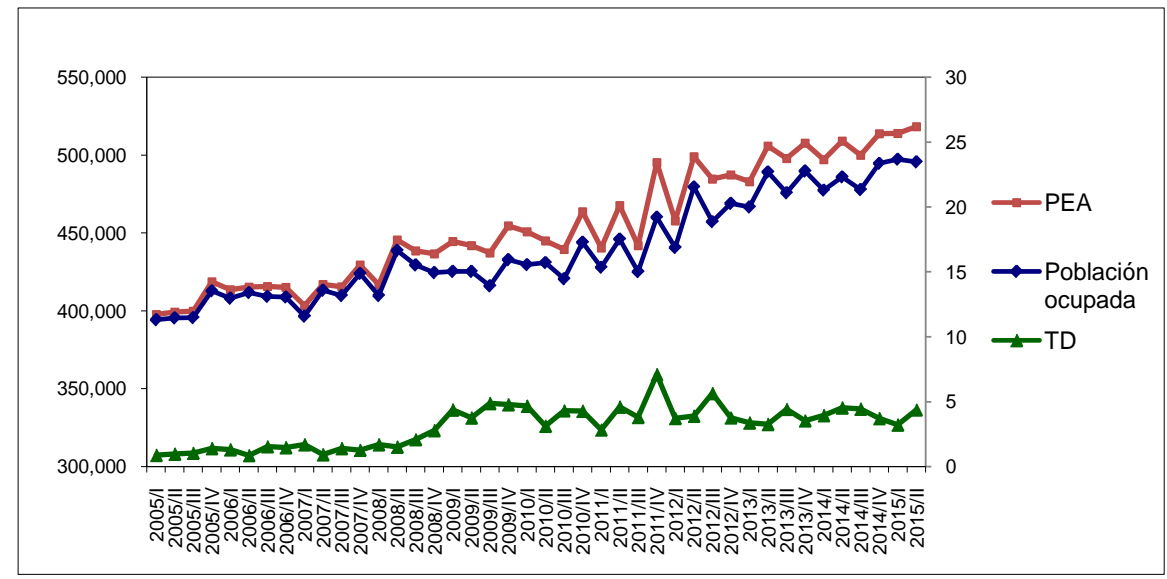

Figure 8. PO, PEA and TD in Mexicali. Source: Own elaboration.

However, the great agricultural activity causes that Oaxaca (with 3411) is the second State in importance; after Sonora, Guerrero and Baja California Sur are located (with 2778, 2217 and 1558, respectively). Ensenada is a municipality in which the PEA of a migratory flows Baja California providers is located in one higher level taking place five on flows of people to the municipality. For its part, the economically active population of the four entities with greater presence (Sonora, Oaxaca, Sinaloa and Oaxaca) shows one lower level (Figure 9).

Although in the case of Ensenada three indexes show no variability as high as in the other municipalities, its evolution generates a strong pressure on the labor market due to the existence of two special phenomena in the municipality: on one hand the agricultural sector, seasonally, prints certain dynamism and maintains the attraction of migrants; on the other hand, the decrease of the dynamics in the business activities and services associated with the decline in tourism and the crisis of the second mortgages in the U.S. impacted the real estate developments in the coastal area oriented, above all, to satisfy the demand for foreign migrant housing, which generated a strong stagnation in the occupation. This double phenomenon as a whole has led, although the $\mathrm{PO}$ rises in 61,303 people 


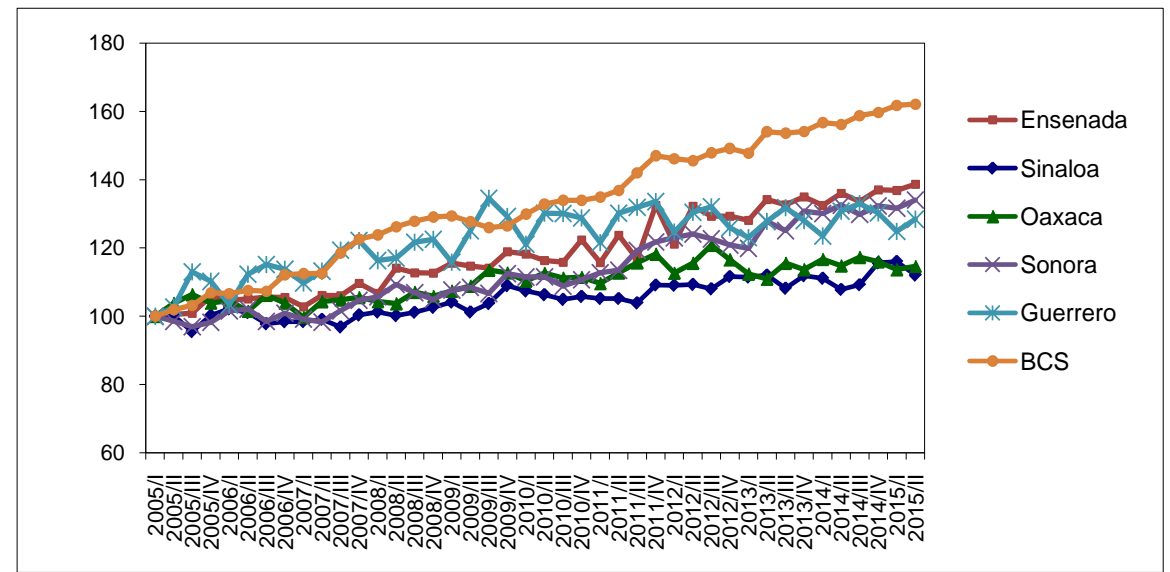

Figure 9. Index of PEA in Ensenada, Oaxaca, Sonora, Sinaloa, Guerrero and Baja California Sur. Source: Own elaboration with INEGI, ENOE data.

in the period, the increase of the PEA in 74339 people raise the TD from $1.2 \%$ to $5.8 \%$ for the second quarter of 2005 to the second in 2015 (see Figure 10).

\subsection{Tecate}

Similar to the other municipalities of the State, its evolution of the PEA shows a performance of greater magnitude than the entities with greater flows of people to the municipality. As in the other municipalities, only during recent periods Sonora shows a notorious performance at a similar level; its growing trend leads to a continuous increase of the distance between them.

In Tecate, the main entities that provide migrants are Sinaloa (1434), Sonora (846), Chiapas (680), Jalisco (561) and Michoacan de Ocampo (440), as it can be seen in Figure 11.

In contrast to Rosarito (and in the same sense as in Tijuana), the impacts on Tecate are very associated with those received by the export manufacturing sector. This situation has led to that, despite an increase in the PO of $30 \%$, the PEA increase of $32 \%$ generated an increase of the TD that underwent a change from 2.4 to $4.5 \%$ (see Figure 12).

\subsection{Playas de Rosarito}

As in Tecate, here is the presence of inhabitants from Sinaloa (914), Jalisco (658) and Michoacan de Ocampo (525). The distinguishing feature between the two municipalities of smaller size in the State is that in Playas de Rosarito, Nayarit is joined as the fourth entity with presence of migrants with 428 people (see Figure 13).

In Playas de Rosarito, just as in the coastal area of the State, in addition to migration, additional pressures are given related to the uncertain recovery of the activities associated with tourism and the real estate market of second mortgages, especially for people of foreign origin. This led to, as shown in Figure 14, despite having increments in the PO and PEA of 54\% and 57\% respectively (by the way, the highest in the State), TD will pass from 2.4 to 4.5 per cent. 


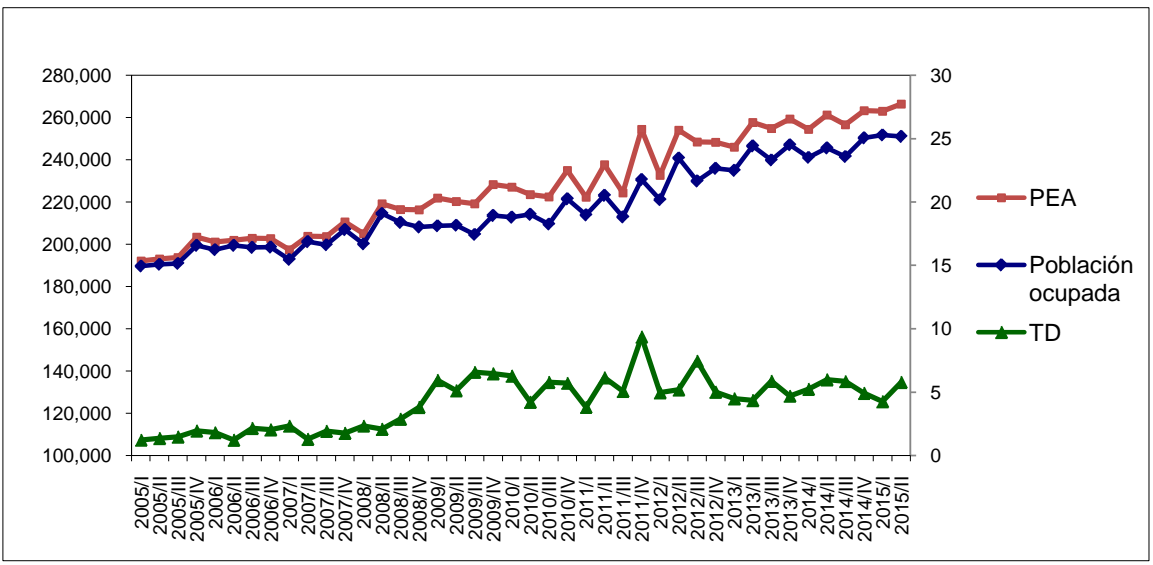

Figure 10. PO, PEA and TD in ensenada. Source: Own elaboration.

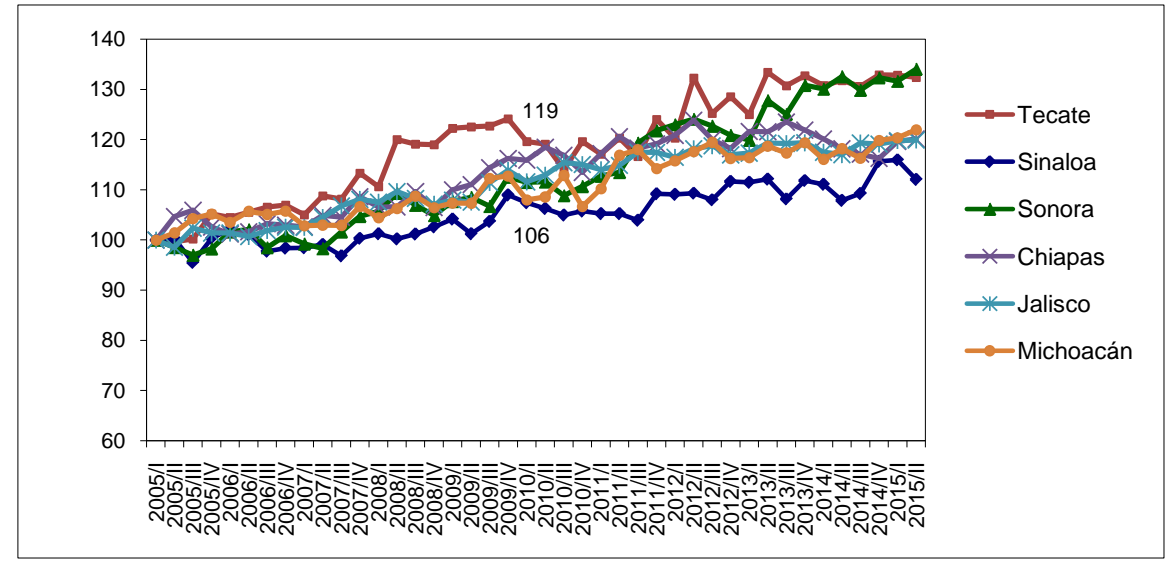

Figure 11. Index of PEA in Tecate, Sinaloa, Sonora, Chiapas, Jalisco and Michoacan de Ocampo. Source: Own elaboration with INEGI, ENOE data.

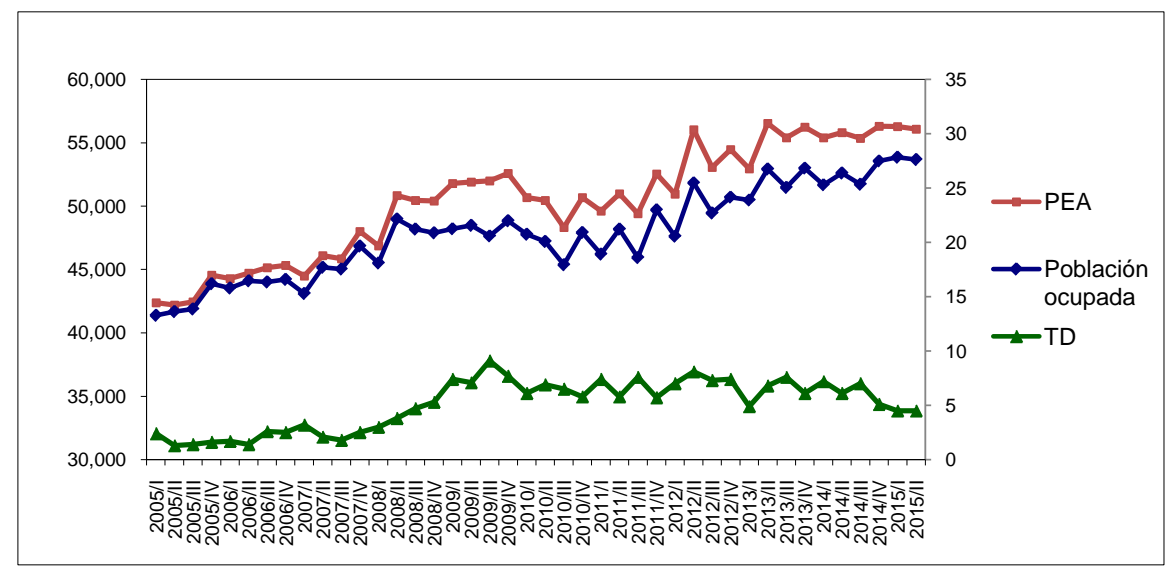

Figure 12. PO, PEA and TD in Tecate. Source: Own elaboration.

As it can be seen, both in the State in general and in each of the municipalities in particular, the migration process has contributed to increase the offer of hand labor available in the labor market, creating pressures to the rise in the TD, nevertheless having an important increase of PO. Which according to Mungaray et al. 


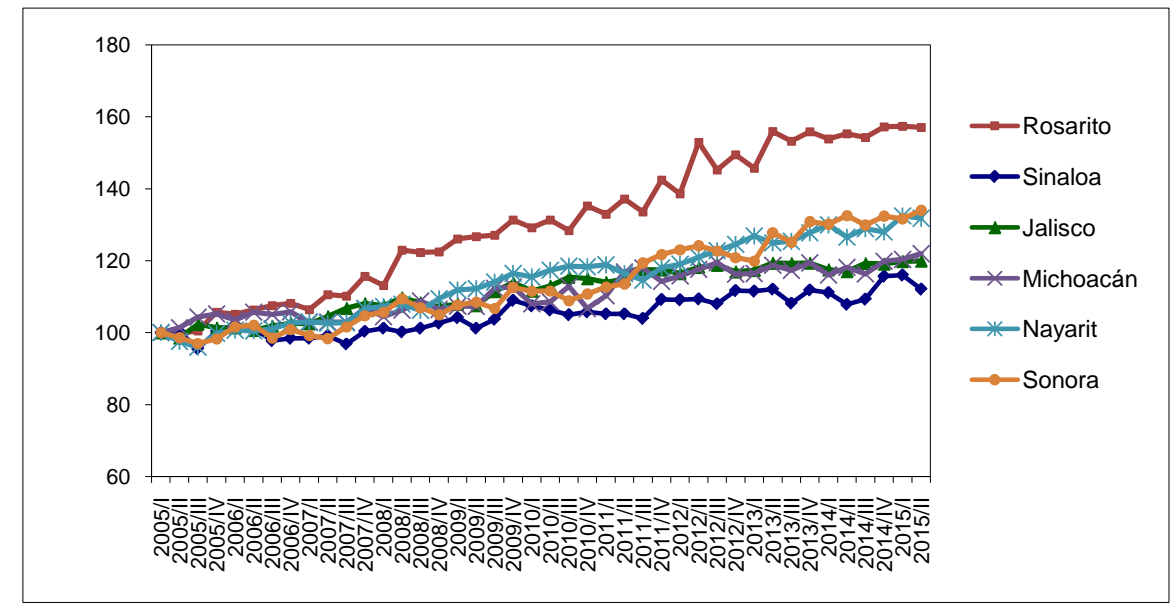

Figure 13. Index of PEA in Playas de Rosarito, Sinaloa, Jalisco, Michoacan de Ocampo, Nayarit and Sonora. Source: Own elaboration with INEGI, ENOE data.

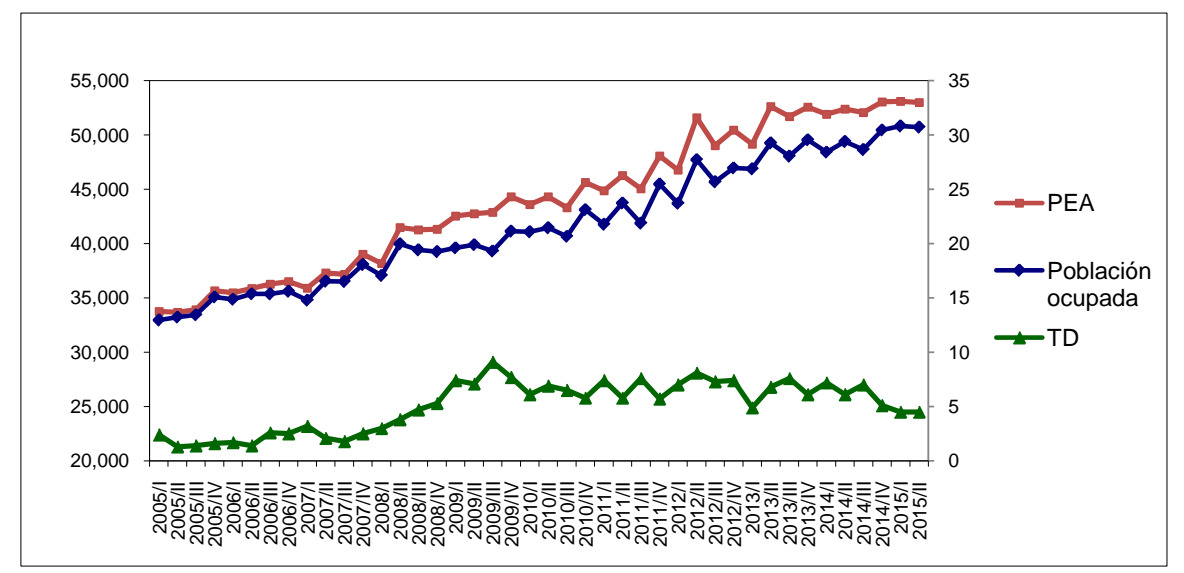

Figure 14. PO, PEA and TD in Playas de Rosarito. Source: Own elaboration.

(2014) “in labor markets such as Baja California's, which has a high migration and free movement of factors, an public effective employment policy generated the so-called 'Todaro' effect, because, by improving the attractiveness of the region as a receptor of migrants, it generated attraction of more migration, which caused a temporary increase in unemployed people." [12].

Inside the reasons influencing this phenomenon there can be mentioned factors associated to: 1) The occupation in the informal sector in the State is the second lowest in the national level, while the main entities that provide migrants are located in places with higher occupation in this sector, Sinaloa (5), Sonora (9), Chiapas (7) and Jalisco (20); 2) Baja California is ranked in fourth place nationally with less occupation in critical conditions and, equally to the previous case, the entities with greater flow of people occupy positions with greater critical conditions, Sinaloa (7), Sonora (5), Chiapas (32) and Jalisco (6) and 3) The level of underemployment in the State is the second lowest in the country, and similarly, Sinaloa, Sonora, Chiapas and Jalisco are found with higher levels of underemployment in places $18,17,13$, and 20 , respectively. 
These elements are decisive in the decisions of the people who prefer to emigrate to places where there are reduced TD but with difficult conditions of occupation, to places with higher TD but with better conditions in the labor market.

\section{Conclusions}

The obtained results indicate that migratory flows in the interior of the country have driven the increase in the PEA, setting up a scenario where the increases in the unemployment rate are imported from entities that expel hand labor towards Baja California. In this phenomenon, above all, the Pacific regions, South and North contribute; at the level of entities Sinaloa, Sonora, Chiapas, Jalisco, Veracruz de Ignacio de la Llave and Michoacan de Ocampo highlight.

At a municipal level, a relatively distinct behavior is observed: in Tijuana as a main provider of migratory flows, Sinaloa, Chiapas, Veracruz de Ignacio de la Llave, Jalisco and Sonora excel.

In Mexicali, most people arrive from Sinaloa and, due to its proximity to the city, from San Luis Rio Colorado, Sonora, although Jalisco, Veracruz de Ignacio de la Llave and Chiapas also have presence. In Ensenada, owing to the importance of agricultural activities, people outstand from Sinaloa, Oaxaca, Guerrero and Baja California Sur. For its part, in Tecate and Rosarito the presence of Sinaloa, Sonora, Jalisco and Michoacan de Ocampo is mantained; However, while in Tecate, Chiapas has greater presence, in Rosarito a greater migration from Nayarit can be observed.

A distinctive feature of the phenomenon of increase in the PEA in Baja California is that even in time of crisis and uncertain recovery, which the world economy is facing, the State maintains as a departure to the problematic of occupation in the entities mentioned.

Estimates show common trends (although in different magnitudes) in the municipalities of the entity. Between 2005 and the second quarter of 2015, Mexicali shows an increase of the PO of $26 \%$ and the PEA of $30 \%$, which leads to a change in the TD from $10 \%$ to $4.4 \%$; in Ensenada an increase is observed in the PO of $32 \%$ and in the PEA of $39 \%$, with a TD that increased from $1.2 \%$ to $5.8 \%$; in Tecate and Playas de Rosarito the increases in the PO were 30\% and 54\% and in the PEA 32\% and 57\%, while the TD changed in the same magnitude in both municipalities from $2.4 \%$ to $4.5 \%$. Finally, in Tijuana the PO increased $27 \%$, while the PEA increased 30\%, which led to a change in the TD from 2.4 to 4.5 , by the way.

In sum, the estimates at a municipal level confirm a paradoxical phenomenon in Baja California, because as the employed population increases, the unemployment rate rises, both at the same time. This happens as a consequence of the fact that the occupied population surge fails to compensate the increases in the PEA, derived from the strong migratory flows in the interior of the country.

\section{References}

[1] Diario Oficial de la Federación (2015) Ley del Seguro Social. 
http://www.imss.gob.mx/sites/all/statics/pdf/leyes/LSS.doc

[2] Elizondo, R.L. and Krugman, P. (1992) Trade Policy and the Third World Metropolis. Working Paper No. 4238, National Bureau of Economic Research, Inc., Cambridge, MA.

[3] Hanson, G.H. (1994) Regional Adjustment to Trade Liberalization. Working Paper No. 4713, National Bureau of Economic Research, Inc., Cambridge, MA.

[4] Hanson, G.H. (1997) Increasing Returns, Trade and The Regional Structure of Wages. The Economic Journal, 107, 113-133.

https://doi.org/10.1111/1468-0297.00145

[5] Chamboux-Leroux, J.-I. (2001) Efectos de la apertura comercial en las regiones y la localización industrial en México. Comercio Exterior, 51, No. 7.

[6] Dávila, A. (2004) México: Concentración y localización del empleo manufacturero, 1980-1998. Economía Mexicana. Nueva Época, 53, No. 2.

[7] Ocegueda, J.M. (2001) Balanza comercial y crecimiento económico de Baja California. Comercio Exterior, 51, No. 3.

[8] Ocegueda, J.M. (2005) Comercio y crecimiento económico en Baja California. Investigación Económica, 64, No. 251.

[9] Mungaray, A. and Cabrera, C. (2003) Especialización industrial y desarrollo empresarial en Baja California. Región y Sociedad, 15, No. 27.

[10] Marshall, A. (1927) Principles of Economics. Londres, Macmillan and Co., Limited.

[11] Mendoza, J.E. (2010) El mercado laboral en la frontera norte de México. Estudios Fronterizos. Nueva Época, 11, No. 21.

[12] Mungaray, A., Escamilla, A. and Garcia, E. (2014) Migración por empleo en México. La experiencia de Baja California entre 2008 y 2012. Región y Sociedad, 26, No. 61. 